\title{
The rate and indications of caesarean section in a tertiary care hospital at Jaipur, India
}

\author{
Meeta Gupta*, Vineeta Garg
}

Department of Obstetrics and Gynecology, RUHS College of Medical Sciences, Jaipur, Rajasthan, India

Received: 16 March 2017

Accepted: 28 March 2017

*Correspondence:

Dr. Meeta Gupta,

E-mail: swasthyamangalam@gmail.com

Copyright: (c) the author(s), publisher and licensee Medip Academy. This is an open-access article distributed under the terms of the Creative Commons Attribution Non-Commercial License, which permits unrestricted non-commercial use, distribution, and reproduction in any medium, provided the original work is properly cited.

\section{ABSTRACT}

Background: Caesarean section is one of the most widely performed surgical procedures in obstetrics worldwide. It was mainly evolved as a lifesaving procedure for mother and foetus during the difficult delivery. To analyze the rate and indications for C-Section and associated maternal morbidity and mortality were the main objectives of present study.

Methods: This retrospective study was conducted over a period of one year from $1^{\text {st }}$ Jan 2016 to $31^{\text {st }}$ Dec 2016 at the Department of OBG, RUHS College of Medical Sciences, Jaipur (Rajasthan), North India. Data of patients who delivered by C-Section in our hospital during the defined study period was recorded and a statistical analysis of various parameters namely, the caesarean section rates, its indications, the patient's morbidity and mortality was done.

Results: The total numbers of women delivered over the study period were 2959, out of which C-Sections were 931. The overall CS rate was $31.46 \%$. Previous LSCS was the leading indication to the CS rate $(36.52 \%)$ followed by arrest of labour $(13.65 \%)$, CPD (12.03\%), foetal distress (11.82\%), breech presentation $(7.52 \%)$, oligohydroamnios/IUGR $(5.16 \%)$ and failed induction of labour (3.54\%). $11.60 \%$ patients had various complications mainly infection $(5.58 \%)$ and haemorrhage $(3.98 \%)$. There was no mortality during this period.

Conclusions: Being a tertiary care hospital, a high rate of Caesarean deliveries was observed. Individualization of the indication and careful evaluation, following standardized guidelines, practice of evidenced-based obstetrics and audits in the institution, can help us limit CSR.

Keywords: Caesarean section, Caesarean rates, Indications of CS

\section{INTRODUCTION}

Caesarean section is one of the most widely performed surgical procedures in obstetrics worldwide. It was mainly evolved as a lifesaving procedure for mother and foetus during the difficult delivery. There is progressive increase in caesarean deliveries across the world; in developed as well developing countries. ${ }^{1}$ This increase in C-Section Rate has become a major public health issue, because

- It is a burden on health system and imposes strain on families. $^{2}$
- It had been observed that caesarean deliveries are associated with increased risk of maternal and perinatal morbidity as compared to vaginal deliveries even in low risk cases. ${ }^{3}$

- The rapid increase in caesarean birth rates from 1996 to 2011 without clear evidence of concomitant decreases in maternal or neonatal morbidity or mortality raises significant concern that caesarean delivery is overused. ${ }^{4}$

The indications of caesarean sections vary among institutions as there is no standard classification system exists for indications of $\mathrm{C}$-Section. ${ }^{5,6} \mathrm{~A}$ major challenge is 
that definitions are not standardized and indications can be multiple or related. ${ }^{7}$ The most common indications for primary caesarean delivery include, in order of frequency, labor dystocia, abnormal or indeterminate foetal heart rate tracing, foetal malpresentation, multiple gestation, and suspected foetal macrosomia. ${ }^{4}$ In order to understand the degree to which caesarean deliveries may be preventable, it is important to know why caesareans are performed. This study is aimed to find the rate of caesarean deliveries, various indications of the procedure and their relative contribution to the total CSR as well associated maternal morbidity and mortality. This is a step to find out indications of LSCS which may help us to reduce the incidence rate in the institute in future.

\section{METHODS}

To observe the caesarean delivery rate and various indications contributing, the data were collected in a retrospective manner from all the deliveries that occurred during one year period between $1^{\text {st }}$ Jan 2016 to $31^{\text {st }}$ Dec 2016 in the department of obstetrics and Gynaecology, Government RDBP Jaipuriya Hospital. This is a teaching hospital attached to RUHS-College of Medical Sciences, Jaipur (Rajasthan).

Data on all live births were collected. In cases of caesarean sections their indications were recorded along with other demographic profile like age, residence-urban/rural. Whether procedure was done as an emergency or it was a planned surgery. Previous obstetrics history and present obstetric parameters like antenatal care, gestational age, lie and presentation, no. of foetuses, birth weight etc. were also recorded in the format and later entered in the Microsoft excel sheet. Complications during surgery and post-operative period were also recorded.

The various categories of indications for caesarean sections included foetal distress, repeat caesarean section, failed induction, arrest of labour, multiple gestation, malpresentation, cephalopelvic disproportion, foetal indications, maternal indications and obstetric indications. Foetal indications included growth retarded foetuses, prematurity, big baby $>3.5 \mathrm{~kg}$ and congenital malformations in which vaginal delivery was not possible. Maternal indications are the maternal conditions present before pregnancy that could complicate delivery like VVF repair, previous uterine surgery like myomectomy, medical causes that could complicate during labour like heart disease and advanced age. Obstetric indications are the conditions associated with present pregnancy like placenta previa, abruption, placenta accreta, cord prolapsed, pre-eclampsia/ eclampsia etc.

Total, primary and repeat caesarean deliveries were calculated. The caesarean rate was calculated as the number of caesarean birth in a year divided by total number of deliveries in that year. The rate for each indication was calculated annually as the number of caesarean births performed for each indication per 1,000 live births.

One of the limitations in our study is that we are not considering neonatal outcome and remote complications associated with caesarean sections.

\section{RESULTS}

There were a total of 2959 deliveries during the study period, out of which, 931 had delivered via C-Section. The overall C-Section rate was $31.46 \%$. The rate of primary CS was $63.48 \%$. $62.08 \% \mathrm{CS}$ were done as emergency procedure. CPD, previous $\geq 2 \mathrm{CS}$ and malpresentation were the commonest indications for elective CS (Table 1).

Table 1: The caesarean section rates.

\begin{tabular}{|llc|}
\hline Mode of delivery & No. of cases & $\%$ \\
\hline Vaginal delivery & 2028 & 68.54 \\
\hline Abdominal delivery & 931 & 31.46 \\
\hline Primary/Repeat & & \\
\hline Primary sections & 591 & 63.48 \\
\hline Repeat sections & 340 & 36.52 \\
\hline Type of C-section & & \\
\hline Emergency CS & 578 & 62.08 \\
\hline Elective CS & 353 & 37.92 \\
\hline
\end{tabular}

Maximum no. of C-sections was in the age group of 20-25 years $(68.53 \%)$ followed by $21.58 \%$ patients in the age group of 26-30 years. These two groups constituted nearly $90 \%$ of total C-Sections. Only $1.18 \%$ of the cases belonged to the elderly age group of above 35 years. Maximum no. of caesarean sections was in multiparous females $(53.82 \%)$.

Table 2: Demographic analysis of patients who underwent C-section.

\begin{tabular}{|c|c|c|}
\hline Age group & No. of cases & $\%$ \\
\hline 19 years and below (teens) & 30 & 3.23 \\
\hline 20-25 Years & 638 & 68.53 \\
\hline 26-30 Years & 201 & 21.58 \\
\hline 31-35 Years & 51 & 5.43 \\
\hline Above 35 Years & 11 & 1.18 \\
\hline \multicolumn{3}{|l|}{ Parity } \\
\hline Primipara & 430 & 46.18 \\
\hline Multipara (G2-G4) & 490 & 52.64 \\
\hline Grand multipara (G5+) & 11 & 1.18 \\
\hline \multicolumn{3}{|l|}{ Antenatal Status } \\
\hline Booked & 636 & 68.31 \\
\hline Unbooked & 295 & 31.69 \\
\hline \multicolumn{3}{|l|}{ Residence } \\
\hline Urban & 674 & 72.39 \\
\hline Rural & 257 & 27.61 \\
\hline
\end{tabular}

Out of 931 caesarean deliveries $72.39 \%$ were from urban area. Also, result showed that only $68.31 \%$ of women were booked for antenatal care (Table 2). 
Table 3: Percentage of $\mathrm{C}$-section in relation to period of gestation.

\begin{tabular}{|lll|}
\hline Period of gestation & No. of cases & $\%$ \\
\hline Preterm $(<37$ weeks $)$ & 59 & 6.33 \\
\hline Term $(\geq 37$ weeks $)$ & 843 & 90.54 \\
\hline Post term $(\geq 42$ weeks $)$ & 29 & 3.11 \\
\hline Total & $\mathbf{9 3 1}$ & $\mathbf{1 0 0 \%}$ \\
\hline
\end{tabular}

$90.54 \%$ of the study group were term patients (Table 3 ).

Table 4: Indications of C-section.

\begin{tabular}{|lll|}
\hline Indications & No. of cases & $\%$ \\
\hline Previous C-Section & 340 & 36.52 \\
\hline Arrest of Labour & 127 & 13.65 \\
\hline CPD & 112 & 12.03 \\
\hline Foetal Distress & 110 & 11.82 \\
\hline Breech & 70 & 7.52 \\
\hline Oligohydroamnios/IUGR & 48 & 5.16 \\
\hline Failed Induction & 33 & 3.54 \\
\hline PIH & 33 & 3.54 \\
\hline Obstructed labour & 27 & 2.90 \\
\hline APH & 13 & 1.40 \\
\hline BOH & 06 & 0.64 \\
\hline Malpresentation & 05 & 0.53 \\
\hline Multifetal gestation & 03 & 0.32 \\
\hline $\begin{array}{l}\text { Medical disorders } \\
\text { (excluding HDP) }\end{array}$ & 02 & 0.21 \\
\hline Cord prolapse & 01 & 0.11 \\
\hline Prematurity & 01 & 0.11 \\
\hline Total & 931 & 100 \\
\hline
\end{tabular}

Table 5: Indications contributing to the repeat caesarean rate.

\begin{tabular}{|lcc|}
\hline Indications & No. of cases & $\%$ \\
\hline Foetal distress & 111 & 32.65 \\
\hline Scar tenderness & 71 & 20.87 \\
\hline CPD & 54 & 15.88 \\
\hline$\geq 2$ caesareans section & 43 & 12.65 \\
\hline PIH & 11 & 3.24 \\
\hline Refusal of vaginal birth & 11 & 3.24 \\
\hline Breech & 10 & 2.94 \\
\hline Oligohydroamnios/IUGR & 10 & 2.94 \\
\hline Big baby (BW 3.5 kg and more) & 5 & 1.47 \\
\hline Multifetal gestation & 4 & 1.18 \\
\hline Malpresentation & 3 & 0.88 \\
\hline APH & 2 & 0.59 \\
\hline Prematurity & 2 & 0.59 \\
\hline Medical disorders & 2 & 0.59 \\
(excluding HDP) & & \\
\hline BOH & 1 & 0.29 \\
\hline Total & $\mathbf{3 4 0}$ & $\mathbf{1 0 0}$ \\
\hline
\end{tabular}

Among the indications, it was observed that repeat $\mathrm{C}$ section $(36.52 \%)$ was the commonest cause followed by arrest of labour (13.65\%), cephalo-pelvic disproportion $(12.03 \%)$ and foetal distress $(11.82 \%)$ (Table 4).

Commonest cause for the repeat C-Section was foetal distress $(32.65 \%)$ followed by scar tenderness $(20.87 \%)$ and CPD (15.88\%) (Table 5).

Table 6: Maternal morbidity and mortality.

\begin{tabular}{|lll|}
\hline Complications & No. of cases & $\%$ \\
\hline Wound infection-minor & 41 & 4.40 \\
\hline Atonic PPH & 28 & 3.01 \\
\hline Minor bladder injury & 13 & 1.39 \\
\hline UTI & 11 & 1.18 \\
\hline Intra operative haemorrhage & 9 & 0.97 \\
\hline Anaesthetic complications & 5 & 0.54 \\
\hline Gaped wound & 1 & 0.11 \\
\hline Total & $\mathbf{1 0 8} / \mathbf{9 3 1}$ & $\mathbf{1 1 . 6 0}$ \\
\hline
\end{tabular}

$11.60 \%$ patients had complications like infections $(5.58 \%)$, haemorrhage $(3.98 \%)$, operative injury (1.39\%) and anaesthetic $(0.54 \%)$ complications (Table 6).

\section{DISCUSSION}

\section{The changing trends in caesarean deliveries}

There has been a steady increase in the rates of CS in both developed and developing countries (Table 7). ${ }^{7-14}$

Table 7: The changing trends in caesarean deliveries.

\begin{tabular}{|c|c|c|}
\hline Study & Place of Study & $\begin{array}{l}\text { Trends } \\
\text { observed }\end{array}$ \\
\hline G Singh et al & $\begin{array}{l}\text { Agroha, } \\
\text { Haryana }\end{array}$ & $\begin{array}{l}2007-31.0 \% \\
2012-51.1 \%\end{array}$ \\
\hline R.Subhashini et al & $\begin{array}{l}\text { Visakhapatnam, } \\
\text { Andhra Pradesh }\end{array}$ & $\begin{array}{l}2004-16.14 \% \\
2009-20.33 \% \\
2014-25.66 \%\end{array}$ \\
\hline Yadav RG & $\begin{array}{l}\text { Vadodara, } \\
\text { Gujarat }\end{array}$ & $\begin{array}{l}2004-23.48 \% \\
2013-28.87 \%\end{array}$ \\
\hline Manjulatha B et al & $\begin{array}{l}\text { Tirupati, } \\
\text { Andhra Pradesh }\end{array}$ & $\begin{array}{l}2002-16.60 \% \\
2007-18.20 \% \\
2012-22.40 \%\end{array}$ \\
\hline Shabnam S & $\begin{array}{l}\text { Kolkata } \\
\text { West Bengal }\end{array}$ & $\begin{array}{l}1973-9.50 \% \\
2012-40.10 \%\end{array}$ \\
\hline Mittal Shiba et al & $\begin{array}{l}\text { Mumbai, } \\
\text { Maharashtra }\end{array}$ & $\begin{array}{l}2001-17.15 \% \\
2006-23.47 \% \\
2011-28.93 \%\end{array}$ \\
\hline Barber et al & & $\begin{array}{l}2003-26.00 \% \\
2009-36.50 \%\end{array}$ \\
\hline Ba'aqeel & & $\begin{array}{l}1997-10.60 \% \\
2006-19.10 \%\end{array}$ \\
\hline
\end{tabular}

The reasons for the increased caesarean are multifaceted. Commonly cited causes are: ${ }^{10,15,16}$

- Increased institutional deliveries. 
- Avoiding difficult manipulative or instrumental vaginal deliveries.

- Foetal distress detected especially with the use of continuous electronic foetal monitoring.

- Liberal use of caesarean in high risk cases like Breech presentation, previous caesarean delivery, growth retarded foetus, multiple pregnancy, preterm baby.

- Improved safety of C-section with better surgical techniques, anaesthesia, better availability of blood and its products, advanced antibiotics.

- Fear of the patient for labour pain.

- Busy schedule of the obstetrician specially those working in private sector and also an apprehension of the obstetrician regarding the fear of poor neonatal outcome.

It is also possible that caesarean section rates were overestimated since vaginal deliveries at home may have been underreported.

\section{The caesarean section rates}

In this study the rate of caesarean section observed is $31.46 \%$, which is almost double the accepted upper norm of WHO ie. $15 \% .^{16}$

Table 8: The caesarean section rates

\begin{tabular}{llll|}
\hline Study & Place & Study Period & CSR \% \\
\hline Present study & Jaipur, Rajasthan & Jan 2016-Dec 2016 & 32.46 \\
\hline G Singh et al & Agroha, Haryana & Jan 2012-Dec 2012 & 51.1 \\
\hline R.Subhashini et al & Visakhapatnam, Andhra Pradesh & Jan 2014-Dec 2014 & 25.66 \\
\hline Yadav RG & Vadodara, Gujarat & Jan 2013-Dec 2013 & 28.87 \\
\hline Manjulatha B et al & Tirupati, Andhra Pradesh & Jan 2012-Dec 2012 & 22.20 \\
\hline Mittal Shiba et al & Mumbai, Maharashtra & Jan 2011-Dec 2011 & 28.93 \\
\hline Samdal LJ at al & Rural Nepal & Aug 2014-Aug 2015 & 9.50 \\
\hline Jawa A et al & Jaipur, Rajasthan & Dec 2015-May 2016 & 31.80 \\
\hline Preetkamal et al & Vallah, Amritsar, Punjab & May 2015-Apr 2016 & 33.20 \\
\hline Yadav S et al. & Mullana, Ambala, Haryana & Apr 2015-Mar 2016 & 21.60 \\
\hline Saxena N et al & Dehradun, Uttarakhand. & Jan 2015-Dec 2015 & 31.40 \\
\hline Sarma P et al & Sonitpur, Assam & Jan 2015-Dec 2015 & 27.60 \\
\hline Chavda D at al & Rajkot, Gujarat & Jan 2015-Sep 2015 & 19.90 \\
\hline Nikhil A et al & Sola, Gujarat & Jun 2013-Dec 2013 & 25.18 \\
\hline Prashant Bade et al & Latur, Maharashtra & Mar 2013-Aug 2013 & 23.97 \\
\hline Padmaleela K et al & Andhra Pradesh & Apr 2011-Mar 2012 & 31.00 \\
\hline Liu et al & Mainland China, multicentre & Jan 2011-Dec 2011 & 54.90 \\
\hline Santhanalakshmi C et al & Maduranthagam, Tamil Nadu & Jan 2011-Dec 2014 & 12.5 \\
\hline Bhasin SK at al & East Delhi, India & Sep 2003-May 2004 & 34.40 \\
\hline Kambo I et al & 30 medical colleges/teaching hospitals in India & 1998-1999 & 25.40 \\
\hline
\end{tabular}

The present study is conducted in a tertiary care hospital attached to medical college. As such, the most of the cases attending the OPD and also those availing the emergency services are basically referred cases from the nearby and also some of the distant PHC (Primary Health Centre), CHC (Community Health Centre), Sub divisional Dispensaries and the Civil Hospitals. Given the situation, it may be difficult to curtail the rates in tertiary care institutes, catering to a large population of referred cases.

There exists a wide variation in caesarean rates between the developed and developing countries. The caesarean section rate in Africa was $6.2 \%$ where as in United Kingdom; the CSR was $24.1 \%$ of all live births. ${ }^{17,18} \mathrm{~A}$ study by Samdal LJ et al from rural Nepal reported CSR of $9.5 \% .{ }^{19}$ Average annual CSR in the present study can be compared with the other studies (Table 8). ${ }^{7-10,12,19-32}$

\section{The caesarean section indications}

In the present study, the most common indication was previous caesarean section $(36.52 \%)$. Similar results were found in studies conducted by G Singh et al, Jawa A et al, Chavda D et al, Nikhil A et al, Prashant Bade et al and Osman BALCI et al. ${ }^{7,20,25-27,33}$

Practice of trial for vaginal birth after caesarean (VBAC) is less in our hospital due to doubtful scar strength, details regarding previous $\mathrm{CS}$ being not available, more no. of deliveries being conducted in the institution and more no. of referrals in late stage of labour. No trial was given to patients with previous 2 or more sections, those who presented with scar tenderness, in those previous sections was done for pelvic abnormalities and also in those women who refused for vaginal delivery. ${ }^{34}$ 
Table 9: The caesarean section indications.

\begin{tabular}{|lclllllll|}
\hline Indications & $\begin{array}{l}\text { Present } \\
\text { Study }\end{array}$ & $\begin{array}{l}\text { Sarna P } \\
\text { et al }\end{array}$ & $\begin{array}{l}\text { Jawa A } \\
\text { et al }\end{array}$ & $\begin{array}{l}\text { Chavda } \\
\text { D et al }\end{array}$ & $\begin{array}{l}\text { Prashant } \\
\text { Bade et } \\
\text { al }\end{array}$ & $\begin{array}{l}\text { Nikhil } \\
\text { A et al }\end{array}$ & $\begin{array}{l}\text { Osman } \\
\text { BALCI } \\
\text { et al }\end{array}$ & $\begin{array}{l}\text { G } \\
\text { Singh } \\
\text { et al }\end{array}$ \\
\hline Previous C-section & $36.52 \%$ & $23.00 \%$ & $23.90 \%$ & $39.90 \%$ & $24.80 \%$ & $42.09 \%$ & $36.77 \%$ & $29.70 \%$ \\
\hline Arrest of labour & $13.65 \%$ & $2.99 \%$ & $13.00 \%$ & $0.90 \%$ & $16.60 \%$ & $10.94 \%$ & - & $25.40 \%$ \\
\hline CPD & $12.03 \%$ & $2.02 \%$ & $5.93 \%$ & $4.80 \%$ & $17.60 \%$ & $6.32 \%$ & $9.88 \%$ & $5.10 \%$ \\
\hline Foetal distress & $11.82 \%$ & $30.99 \%$ & $16.06 \%$ & $19.10 \%$ & $11.70 \%$ & $10.94 \%$ & $13.17 \%$ & $12.1 \%$ \\
\hline Breech/malpresentation & $8.05 \%$ & $3.03 \%$ & $9.37 \%$ & $18.6 \%$ & $6.80 \%$ & $8.26 \%$ & $5.48 \%$ & $11.3 \%$ \\
\hline Oligohydroamnios/IUGR & $5.16 \%$ & $5.00 \%$ & $5.93 \%$ & $2.00 \%$ & $4.00 \%$ & $3.89 \%$ & - & - \\
\hline Failed induction & $3.54 \%$ & $14.00 \%$ & - & $7.30 \%$ & $2.90 \%$ & - & $3.11 \%$ & - \\
\hline PIH & $3.54 \%$ & $12.99 \%$ & $11.66 \%$ & - & - & $1.94 \%$ & $4.20 \%$ & $4.80 \%$ \\
\hline
\end{tabular}

The second common indication in the present study was arrest of labour (13.65\%). The increase in labour arrest disorders is possibly because of decrease in the difficult instrumental deliveries over a period of time in our institute.

Foetal distress accounted for $11.82 \%$; Breech-7.52\%; Oligohydramnios/IUGR-5.16\%; failed induction-3.54\%; PIH accounted for $3.54 \%$. Rest in decreasing order were obstructed labour, APH, BOH, malpresentation, multifetal gestation, medical disorders excluding HDP, cord prolapsed and prematurity.

The indications of caesarean section in the present study can be compared with the following studies (Table 9). ${ }^{7,20,24-27,33}$

\section{Demographic profile}

Analysis of age of the patients showed that $90.11 \%$ of cases were in the age group of maximum fertility i.e. between 20-30 years. Other Indian studies also showed similar results. ${ }^{20,24} \mathrm{~A}$ study of Latin American hospital showed maximum incidence in $>30$ years primi patients, which might reflect delayed age of marriages in the western countries. ${ }^{35}$

In the present study $72.39 \%$ women undergone for CS were from urban area while $27.61 \%$ women belonged to rural area. This indicates the awareness among rural women and the improved transport facilities.

\section{Maternal morbidities and mortalities}

The caesarean sections were associated with increased risk of maternal and perinatal morbidity as compared to vaginal deliveries even in low risk cases. ${ }^{36}$ In our study, the morbidity rate was found as $11.60 \%$. Surgical site infection $(4.40 \%)$ was the commonest complication followed by atonic PPH (3.01\%). These complications occur especially in emergency cases.
In a study by Santhanalakshmi $\mathrm{C}$ et al, the commonest complication was wound infection (38\%). The next common complications were UTI, post op fever and spinal headache, $20 \%, 19 \%$, and $14.4 \%$ respectively. ${ }^{30}$

In a study by Osman BALCI et al the morbidity rate was found as $14 \%$. Febrile morbidity was detected as the most common with $11 \% .{ }^{17}$ Postoperative endometritis, urinary tract infection and wound infection rates were detected $1.28 \%, 1.09 \%$ and $0.73 \%$ respectively. ${ }^{33}$

\section{CONCLUSION}

Greatest emphasis attached to foetal welfare in today's small family norm has changed the delivery practices in favour of C-Section. There is no empirical evidence for an optimum percentage. What matters most is that all women who need caesarean sections receive them (WHO Statement 2010). Safe reduction of the rate of primary caesarean deliveries will require different approaches for each indication. Individualization of the indication and careful evaluation, following standardized guidelines, practice of evidenced-based obstetrics and audits in the institution, can help us limit CSR.

\section{ACKNOWLEDGEMENTS}

Authors would like to acknowledge the Medical Records Department of our institution for allowing me to access the in-patient record files. Authors would also like to thank Dr Arvind Agrawal, who assisted me in the maintaining the records and preparing the manuscript.

Funding: No funding sources

Conflict of interest: None declared

Ethical approval: The study was approved by the Institutional Ethics Committee

\section{REFERENCES}

1. National Institutes of Health state-of-the-science conference statement. Cesarean delivery on maternal request. Obstet Gynecol. 2006;107:1386-97. 
2. Gibbons L, Belizan JM, Lauer JA, Betran AP, Merialdi M, Althabe F. The Global Numbers and Costs of Additionally Needed and Unnecessary Caesarean Sections Performed per Year: Overuse as a Barrier to Universal Coverage. World Health Report (2010), Background Paper, No 30.

3. Belizán JM, Cafferata ML, Althabe F, Buekens P. Risk of patient choice caesarean. Birth. 2006;33:1679

4. Caughey AB, Cahill AG. Safe prevention of the primarycesarean delivery. Obstetric Care Consensus. 2014;1:2-19.

5. Stanton C, Ronsmans C. Recommendations for routine reporting on indications for caesarean delivery in developing countries. Birth. 2008; 35:204-11.

6. Torloni MR, Betran AP, Souza JP, Widmer M, Allen $\mathrm{T}$, Gulmezoglu M, et al. Classifications for caesarean section: a systematic review. PLoS One. 2011;6:e1456.

7. Singh G, Gupta ED. Rising incidence of caesarean section in rural area in Haryana, India: a retrospective analysis. Internet J Gynecol Obstetr. 2013;17(2):1-5.

8. Subhashini R, Uma N. Changing trends in Caesarean delivery. IAIM. 2015;2(3):96-102.

9. Yadav RG, Maitra N. Examining cesarean delivery rates using the Robson's ten group classification. J Obstet Gynecol India. 2016;66(Suppl 1):1.

10. Manjulatha B, Sravanthi TP. Caesarean section rates in a Teaching Hospital: a ten year review. IOSR J Dent Med Sci. 2015;14(8):1-5.

11. Shabnam S. Caesarean section delivery in India: causes and concerns, international union for the scientific study of population, session 221, assessments of facility-based delivery services.

12. Shiba M, Sachin P, Niranjan M, Janki M. Trends in cesarean delivery: rate and indications. J Obstet Gynecol. 2014;64(4):251-4

13. 26. Barber EL, Lundsberg LS, Belanger K. Indications contributing to the increasing cesarean delivery rate. Obstet Gynecol. 2011;118(1):29-38.

14. Ba'aqeel. Cesarean delivery rates in Saudi Arabia: a ten-year review. Ann Saudi Med. 2009;29(3):179-83.

15. Tolla ${ }^{\circ}$ es MC. Increased rate of Caesarean sectionscauses and consequences. Tidsskr Nor Laegeforen. 2009;129(13):1329-31.

16. WHO Statement on caesarean section rates; 2015, WHO reference number: WHO/RHR/15.02. Available at http://www.who.int/reproductivehealth/publications/ maternal_perinatal_health/cs-statement/en/.

17. Caesarean section rates and indications in subSaharan Africa: a multi-country study from medecins sans frontieres; PLoS One. 2012;7(9):e44484.

18. WHO Euro Health for all database, 2014. Available at http://data.euro.who.int/hfadb/(53).

19. Samdal LJ, Steinsvik KR, Pun P, Dani P, Roald B, Stray-Pedersen B, Bøhler E. J Obstet Gynaecol India. 2016;66(Suppl 1):284-8.

20. Jawa A, Garg S, Tater A, Sharma U. Indications and rates of lower segment caesarean section at tertiary care hospital-an analytical study. Int J Reprod Contracept Obstet Gynecol 2016;5:3466-9.

21. Preetkamal, Kaur H, Nagpal M. Is current rising trend of cesarean sections justified? Int J Reprod Contracept Obstet Gynecol. 2017;6:872- 6.

22. Yadav S, Kaur S, Yadav SS, Thakur B. Analysis of caesarean rate, indications and complications: review from medical college Ambala, Haryana, India. Int J Reprod Contracept Obstet Gynecol. 2016;5:3326-9.

23. Saxena N, Sharma B, Gupta V, Negi KS. A six year appraisal of caesarean delivery at a teaching hospital in Uttarakhand. Int $\mathbf{J}$ Reprod Contracept Obstet Gynecol. 2016;5:4369-72.

24. 18. Sarma P, Boro RC, Acharjee PS. An analysis of indications of caesarean sections at Tezpur medical college and hospital, Tezpur (a government hospital). Int J Reprod Contracept Obstet Gynecol. 2016;5:1364-7.

25. Chavda D, Goswam K, Dudhrejiya K. A cross sectional study of 1000 lower segment cesarean section in obstetrics and gynecology department of $P$. D. U Medical College, Rajkot, Gujarat, India. Int J Reprod Contracept Obstet Gynecol. 2017;6(4):118691.

26. Nikhil A, Desai A, Vijay K, Bhumika K, Riddhi P. Analysis of trends in LSCS rate and indications of LSCS: a study in a Medical College Hospital GMERS, Sola, Ahmedabad. Int J Pharm Bio-Sci. 2015;2(1):1-5.

27. Bade P, Kendre V, Jadhav Y, Wadagale A. An analysis of indications for caesarean section at government medical college, Latur. Intern J Recent Trends Sci Technol. 2014;11(1):6-8.

28. Padmaleela K, Thomas V, Prasad KV. An analysis of the institutional deliveries and their outcomes in government teaching hospitals of Andhra Pradesh, India. IJHSR. 2013;3(5):76-81.

29. Liu Y, Li G, Chen Y, Wang X, Ruan Y, Zou L et al. A descriptive analysis of the indications for caesarean section in mainland China. BMC Pregnancy Childbirth. 2014 Dec 12;14:410.

30. Santhanalakshmi C, Gnanasekaran V, Chakravarthy AR. A retrospective analysis of cesarean section in a tertiary care hospital. 2015;4:2097-9.

31. Bhasin SK, Rajoura OP, Sharma AK, Metha M, Gupta $\mathrm{N}$, Kumar S et al. A high prevalence of caesarean section rate in East Delhi. Indian $\mathrm{J}$ Comm Med. 2007;32(3):222-4.

32. Kambo I, Bedi N, Dhillon BS, Saxena NC. A critical appraisal of caesarean section rates at teaching hospitals in India. Int $\mathbf{J}$ Gynaecol Obstet. 2002;79(2):151-8.

33. Osman BALCI, Kazım GEZGİNÇ, Ali ACAR. The outcome analysis of cesarean section cases in oneyear period. Gynecol Obstet Reprod Med 2007;13:2628.

34. Vaginal birth after caesarean (VBAC): resource overview, 2016. Available at http://www.acog.org/Womens-Health/VaginalBirthAfter-Cesarean-VBAC 
35. Geen JE, Meclean F, Usher SR. Caesarean section study of latin American Hospital. Am J obstet Gynaecol. 1982;142.

36. Mylonas I, Friese K. Indications for and risks of elective caesarean section. Dtsch Arztebl Int. 2015;112(29-30):489-95.
Cite this article as: Gupta M, Garg V. The rate and indications of caesarean section in a teaching hospital at Jaipur, India. Int J Reprod Contracept Obstet

Gynecol 2017;6:1786-92. 